\title{
Suomalaisten yliopistojen avoimet julkaisut vuonna 2016 OKM:n julkaisutiedonkeruun tietojen valossa
}

\author{
Jyrki Ilva \\ Kansalliskirjasto \\ jyrki.ilva@helsinki.fi \\ http://orcid.org/0000-0003-3526-0956
}

\begin{abstract}
The Finnish Open Access monitoring efforts are integrated with the national data collection conducted by CSC - IT Center for Science for the Ministry of Education and Culture. The publication data collected from the CRIS of each participating organization can be browsed at Juuli (www.juuli.fi), a discovery interface developed by the National Library of Finland. Starting from 2016, two separate fields have been used for indicating the OA status of each publication. One of the fields indicates whether the publication is OA via a Gold or a Hybrid channel, and the second field is used for indicating whether it has been deposited into a repository. The OA definition used in the data collection has also been updated to make it as clear as possible. According to the current dataset for the year 2016, 28.9\% of all peer-reviewed articles produced within the Finnish universities were reported as being OA. There was a lot of overlap between Gold/Hybrid and Green OA, as about $60 \%$ of the articles deposited into repositories were already OA via Gold or Hybrid OA publication channels.
\end{abstract}

Asiasanat: open access; tieteellinen julkaisutoiminta; yliopistot; tieteenalat; tilastot

Tieteellisten julkaisujen avoin saatavuus (open access, OA) on viime vuosina nostettu keskeiseksi tavoitteeksi sekä Euroopan yhteisön tasolla että myös Suomessa. Opetus- ja kulttuuriministeriön (OKM) vuonna 2014 käynnistämä Avoin tiede ja tutkimus -hanke on asettanut yhdeksi tavoitteekseen sen, että $65 \%$ suomalaisista tieteellisistä julkaisuista olisi avoimesti saatavilla vuonna 2017, 75 \% vuonna 2018 
ja 90 \% vuonna 2020 (ATT-hanke, ei pvm.). Avointen julkaisujen osuuden lisäämisestä kertoimeksi yliopistojen rahoitusmalliin mahdollisesti vuodesta 2019 alkaen on myös käyty alustavaa keskustelua rahoitusmallista päättävässä työryhmässä.

Näiden tavoitteiden kannalta on ollut ongelmallista, ettei suomalaisten tutkimusorganisaatioiden osalta ole toistaiseksi ollut käytettävissä luotettavaa tietoa siitä, miten suuri osa niiden julkaisuista on avoimesti saatavilla. Julkaisujen OA-statusta mittaavat kansainväliset palvelut ovat vasta kehittymässä (Chawla, 2017). Lisäksi haasteena on se, etteivät ne kata kaikkea suomalaista julkaisutoimintaa. Suomalaisten tekijöiden ja organisaatioiden erotteleminen niiden tiedoista on myös hankalaa.

Jotta OA-julkaisujen osuutta kaikista julkaisuista voitaisiin seurata, tarvitaan kattavat tiedot myös niistä julkaisuista, jotka eivät ole avoimesti saatavilla. Pelkkien OA-julkaisujen tiedot eivät siis riitä. Niinpä kansallisen tason OA-seuranta onkin ollut luontevaa kytkeä osaksi OKM:n julkaisutiedonkeruuta, jossa tutkimusorganisaatioilta kerätään viitetiedot niiden henkilökunnan tuottamista julkaisuista (Ilva, 2015a; OKM, 2016).

OKM uudisti OA-tietojen keruussa käytettyjä tietoelementtejä ja niihin liittyvää ohjeistusta tiedonkeruuvuodesta 2016 alkaen (Ilva, 2017b). Tässä artikkelissa tarkastelen yliopistojen raportoimia vuoden 2016 julkaisutietoja, jotka on kerätty uuden ohjeistuksen mukaisesti. Tavoitteenani on selvittää, miten tietoja on mahdollista hyödyntää ja millaisia kysymyksiä niitä käytettäessä on syytä ottaa huomioon. Samalla pyrin luomaan tilannekuvan siitä, miten julkaisujen avoimuus oli toteutunut suomalaisissa yliopistoissa vuonna 2016.

\section{OKM:n julkaisutiedonkeruu, Virta ja Juuli}

OKM on kerännyt yliopistoilta näiden henkilökunnan tuottamien julkaisujen kuvailutiedot vuodesta 2011 lähtien. Sittemmin julkaisutiedonkeruu on laajentunut kattamaan myös ammattikorkeakoulut, sairaanhoitopiirit ja osan valtion sektoritutkimuslaitoksista. Julkaisutietoja hyödynnetään yliopistojen rahoitusmallissa, jossa 13 \% yliopistojen rahoituksesta jaetaan niiden perusteella. Yliopistoilla on siis selkeä motivaatio saada julkaisunsa raportoitua mahdollisimman kattavasti.

Organisaatioilta julkaisutiedonkeruussa kerättävät tietoelementit määriteltiin alun perin vuosina 2009-2011 toimineessa JURE-projektissa (2010), mutta kenttiä ja niiden kuvauksia on sittemmin täydennetty ja tarkistettu. Keruuseen liittyvä ohjeistus julkaistaan vuosittain tiedonkeruukäsikirjoissa (OKM, 2016). Organisaatioilta kerätään sekä julkaisujen identifiointiin tarvittavat bibliografiset tiedot että muita julkaisuihin, niiden tekijöihin ja taustaorganisaatioihin liittyviä tietoja. Kerättäviä tietosisältöjä on laajennettu varsin maltillisesti, koska tiedonkeruuseen 
osallistuvilla organisaatioilla täytyy olla valmiudet tietojen tuottamiseen ja raportointiin.

Valtakunnallisella tasolla tiedonkeruun prosesseista vastaa CSC, joka kehittää ja ylläpitää tiedonkeruussa käytettyjä järjestelmiä ja niihin liittyvää ohjeistusta. Vuodesta 2016 lähtien julkaisutiedot on raportoitu XML-pohjaisessa formaatissa ja ne on tallennettu CSC:n rakentamaan Virta-palveluun (VIRTA-julkaisutietopalvelu, ei pvm.). Useiden organisaatioiden raportoimien yhteisjulkaisujen osalta Virta yhdistää niiden tiedot yhdeksi tietueeksi. Virrassa on teknisiä rajapintoja, joiden kautta sen sisältämiä tietoja välitetään mm. Kansalliskirjaston ylläpitämään Juuli-portaaliin (www.juuli.fi). Juulissa julkaisutiedot ovat vapaasti saatavilla, niitä voi selata ja niistä voi tehdä tiedonhakuja (Ilva, 2013).

Yliopistojen osalta tiedonkeruuseen raportoidut tiedot ovat peräisin niiden tutkimustietojärjestelmistä. Virran käyttöönoton myötä tiedonkeruun prosesseja on voitu automatisoida siten, että keruuseen osallistuvilla organisaatioilla on mahdollisuus päivittää tietojaan teknisen rajapinnan kautta päivittäin. Kaikilla organisaatioilla ei kuitenkaan vielä ole sellaisia järjestelmiä tai prosesseja, jotka tukisivat tätä. Niinpä osa organisaatioista raportoi julkaisutietonsa edelleen vuosittain, käytännössä tiedonkeruuvuotta seuraavassa maaliskuussa.

\section{Julkaisujen avoin saatavuus OKM:n tiedonkeruussa}

OKM:n julkaisutiedonkeruussa on kerätty tietoa julkaisujen avoimesta saatavuudesta vuodesta 2011 lähtien. Tietojen laadussa oli kuitenkin vuoteen 2015 asti vakavia ongelmia, mistä johtuen niiden antama kuva suomalaisista OA-julkaisuista ei ollut riittävän luotettava esim. yliopistojen rahoitusmallin tarpeisiin. Ongelmien on tulkittu johtuneen sekä OA-tietojen raportoinnissa käytetyistä kategorioista että raportoivien organisaatioiden puutteellisesta motivaatiosta (Ilva, 2015b, 2015a; Olsbo, 2017a).

OKM uudisti vuoden 2016 tiedonkeruuta varten julkaisujen OA-statuksen ilmoittamiseen tarkoitetut kentät ja keruussa sovelletun avoimen saatavuuden määritelmän. Aiemman yhden avoin saatavuus -kentän sijasta tiedonkeruussa on nyt kaksi erillistä kenttää. Toisessa kentistä ilmaistaan onko julkaisu avoimesti saatavilla kustantajan palvelun kautta, osana joko kokonaan tai osittain avointa julkaisukanavaa. Toisessa kentässä puolestaan raportoidaan, onko julkaisu rinnakkaistallennettu (OKM, 2016, ss. 44-46).

Erillisiä kenttiä pidettiin tarkoituksenmukaisina, koska sama julkaisu saattaa olla vapaasti saatavilla sekä kustantajan palvelun kautta että rinnakkaistallenteena. Lisäksi vuodesta 2016 lähtien ryhdyttiin keräämään erikseen tietoa rinnakkaistallenteen verkko-osoitteesta, sillä organisaatiot olivat aiemmin yleensä raportoi- 
neet vain kustantajan version osoitteen. Kustantajien palveluiden kautta toteutuneen avoimuuden osalta tiedonkeruun kenttien suunnittelussa päädyttiin siihen, että OA-julkaisukanavissa ilmestyneet julkaisut ("kultainen OA") erotettiin muissa kanavissa ilmestyneistä yksittäisistä OA-julkaisuista (Ilva, 2017b; OKM, 2016). Tiedonkeruun ohjeistuksessa jälkimmäisiin kanaviin viitataan hybridijulkaisukanavina; toisin kuin joissakin "hybridi-OA:n" (Laakso \& Björk, 2016) määritelmissä oletetaan, OKM:n käyttämässä kategorisoinnissa ei oteta kantaa siihen, onko julkaisujen avoimuudesta maksettu artikkelimaksua.

Osana vuodesta 2016 lähtien toteutettuja uudistuksia myös tiedonkeruussa käytettyä avoimen saatavuuden määritelmää täsmennettiin. Uuden määritelmän mukaan OA-julkaisun pitää olla vähintään vapaasti luettavissa, joidenkin OA-määritelmien (Budapest Open Access Initiative, 2002) edellyttämää julkaisun avointa lisensiointia ei sen sijaan vaadita. Julkaisut voivat olla vapaasti saatavilla joko kustantajan palvelun kautta tai julkaisuarkistoon rinnakkaistallennettuina (Ilva, 2017b; OKM, 2016).

Rinnakkaistallenteiden kohdalla kustantajan asettaman embargoajan noudattaminen on ohjeistuksen mukaan hyväksyttävää, mutta kustantajan palvelun kautta toteutuvan avoimuuden tulee olla välitöntä. Rinnakkaistallenteet voidaan tallentaa joko organisaation omaan tai tieteenalakohtaiseen julkaisuarkistoon, mutta tallentamista esim. projektin verkkosivulle tai ResearchGaten ja Academia.edu:n kaltaisiin, kaupallisista lähtökohdista toimiviin tutkijoiden verkostoitumispalveluihin (Matthews, 2016) ei lasketa avoimeksi saatavuudeksi. Lisäksi määritelmä edellyttää, että julkaisun avoin versio on vertaisarvioitu, eli sen tulee olla joko lopullinen kustantajan palvelussa ilmestynyt versio tai tutkijan viimeinen oma versio (Ilva, 2017b; OKM, 2016).

Määritelmä on pyritty muotoilemaan mahdollisimman yksiselitteiseksi siten, että se samalla vastaa kohtuullisen hyvin yleisimmin käytettyjä kansainvälisiä määritelmiä. Määritelmä jättää joitakin asioita edelleen avoimiksi, sillä se ei ota kantaa esim. embargojen sallittuun enimmäispituuteen. Haasteeksi jää lisäksi se, että kansainväliset määritelmät ovat joiltakin osin keskenään ristiriitaisia ja ne saattavat muuttua ajan myötä.

Hyvä esimerkki määritelmien kasvavasta moninaisuudesta on jo pre print -versiona paljon huomiota saanut artikkeli "The State of OA: A large-scale analysis of the prevalence and impact of Open Access articles" (Piwowar ym., 2017). Artikkelissa määritellään kultainen OA uudelleen ja lanseerataan sen rinnalle uusi kategoria "pronssi-OA". Artikkelissa kultainen OA on rajattu kattamaan vain julkaisukanavat, joissa ilmestyvien julkaisujen oikeudet on määritelty Creative Commons -lisensseillä. Uuteen pronssi-OA-kategoriaan on puolestaan koottu sekä sellaiset välittömästi OA:na julkaistut sisällöt, joilla ei ole CC-lisenssiä että kustantajien palveluissa viiveellä julkaistut avoimet sisällöt ("delayed OA", ks. Laakso \& Björk, 2013). 
Artikkelissa käytetty jaottelu poikkeaa siis oleellisesti OKM:n julkaisutiedonkeruussa käytetystä luokittelusta, jossa OA-julkaisukanavilta ei ole vaadittu CClisenssien käyttöä eikä kustantajien viiveellä julkaisemia sisältöjä ole laskettu ollenkaan OA:ksi. Artikkelissa saadut tulokset eivät siis ole yhteismitallisia tässä tekstissä esiteltävien OKM:n julkaisutiedonkeruussa kerätyn aineiston pohjalta laskettujen lukujen kanssa. Nähtäväksi jää, saako artikkelissa esitetty kategorisointi laajempaa kannatusta.

\section{Yliopistojen vuoden 2016 OA-tiedot}

Kokosin tätä artikkelia varten OKM:n julkaisutiedonkeruun datasta julkaisujen OAstatusta koskevia tietoja, joiden pohjalta pyrin luomaan yleiskuvan avointen julkaisujen osuudesta suomalaisissa yliopistoissa vuonna 2016. Samalla tavoitteenani on ollut osoittaa, miten OKM:n julkaisutietoja on mahdollista hyödyntää tällaisen analyysin tekemisessä ja millaisia asioita niitä tulkittaessa on hyvä ottaa huomioon.

Analyysissä käytetyt tiedot on poimittu Juuli-portaalista pääosin elokuussa 2017. Virran ja Juulin sisältämä data päivittyy useiden yliopistojen osalta jatkuvasti, ja on todennäköistä, että vuoden 2016 julkaisutietoihin tulee muutenkin täydennyksiä ja korjauksia myös tulevina vuosina. Rinnakkaistallenteiden osalta on lisäksi syytä huomata, että kustantajien asettamien embargo-aikojen päättyminen kasvattaa avointen julkaisujen määrää jälkikäteen. Tämänhetkisen ohjeistuksen mukaan embargon alaiset julkaisut voi raportoida jos niiden verkko-osoite on tiedossa (OKM, 2016, s. 46). Usein näin ei kuitenkaan ole. Koska jonkin tietyn ajankohdan tilannetta ei ole enää jälkikäteen mahdollista rekonstruoida, analyysin pohjana käytetyt lukumäärät ja laskelmat on dokumentoitu Kansalliskirjaston julkaisuarkistoon tallennettuun Excel-tiedostoon (Ilva, 2017a).

Vaikka datan laatu on etenkin yliopistojen osalta selkeästi parantunut aiempiin vuosiin verrattuna, on ilmeistä, ettei se vielä ole kaikilta osiltaan tyydyttävä. Tietojen keruu ja tarkistaminen on organisoitu ja resursoitu eri organisaatioissa eri tavoin. Lisäksi Virta-tietovarannossa tehty yhteisjulkaisujen tietueiden yhdistäminen saattaa joiltakin osin vaikuttaa tietojen laatuun - jos organisaatiot ovat ilmoittaneet yhteisjulkaisun OA-statukselle erilaisia arvoja, näistä valitaan yhteisjulkaisun tietueeseen vain yksi. Tällä hetkellä valinta toimii siten, että julkaisukanavan avoimuuden osalta yhteisjulkaisun tietueeseen päätyy sen ensimmäisenä raportoineen organisaation toimittama tieto, kun taas rinnakkaistallennuksen osalta riittää, että yksikin organisaatio on ilmoittanut julkaisun rinnakkaistallennetuksi.

OKM:n tiedonkeruun ohjeistuksen mukaan julkaisun avoimille versioille pitäisi ilmoittaa verkko-osoitteet (OKM, 2016, ss. 44, 47). Käytännössä kaikki organisaatiot eivät ole vielä vuoden 2016 osalta raportoineet näitä osoitteita ainakaan kat- 
tavasti. En ole tässä analyysissä tehnyt erottelua sen suhteen, onko avoimiksi väitetyille julkaisuille ilmoitettu verkko-osoitteita vai ei. Olen pääsääntöisesti luottanut organisaatioiden omaan ilmoitukseen julkaisun avoimuudesta sen sijaan, että olisin ryhtynyt verifioimaan muilla keinoin sitä, ovatko julkaisut todella avoimesti saatavilla.

Koska aiempina vuosina käytetyt kategoriat olivat erilaisia ja datan laatu oli osin tästä johtuen oleellisesti heikompaa, vuoden 2016 tietojen vertaaminen aiempiin vuosiin ei ole mielekästä. Niinpä OA-julkaisuja koskevista trendeistä on mahdollista saada käsitys vasta siinä vaiheessa kun vuoden 2017 data on kattavasti saatavilla. Vertailuja tehtäessä on toki tällöinkin hyvä huomata, että mahdolliset muutokset saattavat OA-julkaisemisessa tapahtuneen kehityksen lisäksi johtua myös raportoitujen tietojen laadussa ja kattavuudessa tapahtuneista muutoksista.

Vaikka korkeakoulujen raportoimissa julkaisujen OA-status-tiedoissa on puutteita, ne ovat ainakin toistaiseksi selkeästi luotettavampia kuin sairaanhoitopiirien tai tutkimuslaitosten vastaavat tiedot. Sairaanhoitopiirien ja tutkimuslaitosten julkaisujen OA-tietojen analysointi ei siten ole tämänhetkisen datan pohjalta mielekästä. Koska ammattikorkeakoulujen julkaisuprofiili poikkeaa merkittävästi yliopistoista - vertaisarvioitujen julkaisujen osuus on ammattikorkeakouluissa suhteellisen pieni - olen lisäksi rajannut analyysini pelkästään yliopistoihin. Ammattikorkeakoulujen yhteiset OA-julkaisujen osuudet on kuitenkin mainittu taulukossa 1 vertailukohtana yliopistoille.

\section{Avointen julkaisujen osuus julkaisutyypeittäin}

OKM:n julkaisutyyppiluokitus kattaa julkaisutyypit A-I, joista kuitenkin vain julkaisutyyppejä A-E ja julkaisutyyppiin G sisältyviä monografia- ja artikkeliväitöskirjoja koskevat tiedot ovat tällä hetkellä saatavissa Juulissa. Julkaisutyyppien erottelu toisistaan on joiltakin osin varsin hienovaraista ja ohjeistuksesta huolimatta eri organisaatioiden tekemissä tulkinnoissa saattaa olla eroja etenkin niissä tapauksissa, joissa luokitusta varten tarvittavia tietoja ei ole ilmaistu selkeästi julkaisussa itsessään. Yliopistojen kannalta erityisen suuri merkitys on sillä, onko julkaisu vertaisarvioitu vai ei, sillä se vaikuttaa suoraan niiden opetus- ja kulttuuriministeriöltä saamaan rahoitusosuuteen (OKM, 2016, ss. 97-108; Pölönen, 2017).

Luokissa A-E julkaisut on ryhmitelty sen mukaan, onko kyse artikkeleista vai monografioista, onko ne vertaisarvioitu vai ei ja onko ne suunnattu joko tiedeyhteisölle, ammatilliselle yleisölle vai ovatko ne suurelle yleisölle suunnattuja yleistajuisia julkaisuja. Lisäksi luokituksessa erotellaan vertaisarvioitujen artikkelien osalta ovatko ne ilmestyneet lehdessä $\left(\mathrm{A}_{1}-\mathrm{A}_{2}\right)$, kokoomateoksessa $\left(\mathrm{A}_{3}\right)$ tai konferens- 


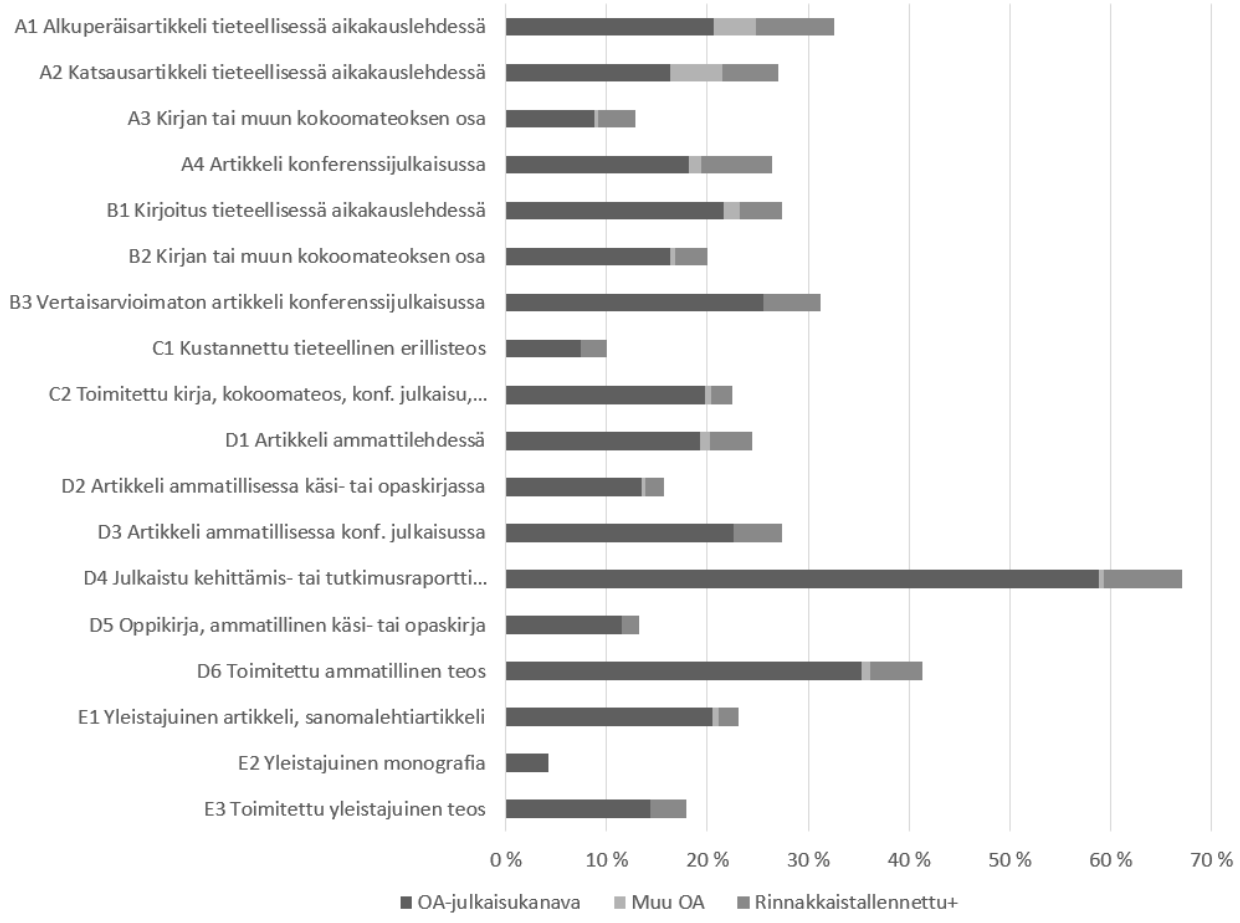

Kuva 1: OA-julkaisujen osuus yliopistojen vuoden 2016 julkaisuista julkaisutyyppien (A1E3) mukaan jaoteltuna.

sijulkaisussa (A4). Tutkijan itse kirjoittamien tekstien lisäksi tietoja kerätään myös toimitetuista teoksista ja lehtien numeroista (C2, D6, E3) (OKM, 2016, ss. 97-106).

Kuten kuva 1 osoittaa, OA-julkaisujen osuus yliopistojen kaikista julkaisuista vaihtelee merkittävästi julkaisutyypistä riippuen. Julkaisutyyppien välillä on myös eroja sen suhteen, millä tavalla avoimuus on toteutunut. Kehittämis- ja tutkimusraporteista ( $\mathrm{D}_{4}$ ) on vapaasti saatavilla jopa kaksi kolmasosaa ja toimitetuista ammatillisista teoksistakin (D6) yli $40 \%$. Muissa julkaisutyypeissä OA-julkaisujen osuus jää kuitenkin alle kolmasosan. Tieteellisten aineistojen osalta on huomionarvoista, että kustannettujen tieteellisten erillisteosten $\left(\mathrm{C}_{1}\right)$ ja kokoomateosten osana ilmestyneiden julkaisujen $\left(\mathrm{A}_{3}\right)$ osalta $\mathrm{OA}$-julkaiseminen on selkeästi lehtiartikkeleita tai konferenssijulkaisuja harvinaisempaa. Yliopistolaisten julkaisemista yleistajuisista monografioista on vapaasti saatavilla alle viisi prosenttia, mikä tuskin on suuri yllätys, koska ne ovat tyypillisimmin myyntiin tarkoitettuja kaupallisia tuotteita.

Jäljempänä esitetyt analyysit OA-julkaisujen osuuksista korkeakouluittain, tieteenaloittain ym. keskittyvät vertaisarvioituihin artikkeleihin (julkaisutyypit A1A4), joissakin tapauksissa vielä rajatummin vertaisarvioituihin lehtiartikkeleihin 
(A1-A2). Rajaus perustuu näiden julkaisutyyppien merkittävyyden ja niihin sisältyvien julkaisujen suuren määrän lisäksi myös siihen, että niitä koskevien tietojen voi olettaa olevan luotettavampia kuin useita muita julkaisutyyppejä koskevat. Koska näillä julkaisutyypeillä on suuri painoarvo yliopistojen rahoitusmallissa, yliopistot ovat todennäköisesti motivoituneita saamaan niitä koskevat tiedot oikein. Tieteellisten lehtien osalta julkaisukanavien OA-statuksen tunnistamiseen on myös käytettävissä erilaisia apuvälineitä (mm. DOAJ- ja Sherpa/Romeo-tietokannat), ja niiden OA-politiikat ovat usein jo lähtökohtaisesti selkeämmin määriteltyjä.

\section{Avointen julkaisujen osuus yliopistoittain}

OKM:lle elokuuhun 2017 mennessä raportoitujen tietojen mukaan yhteensä 28,9\% yliopistojen henkilökunnan vuonna 2016 julkaisemista vertaisarvioiduista artikkeleista oli avoimesti saatavilla. 18,7 \% julkaisuista oli ilmestynyt OA-julkaisukanavassa, $3,4 \%$ oli muuten avoimesti saatavilla kustantajien palvelussa (esim. osana hybridiOA-julkaisukanavaa) ja 18,5\% oli rinnakkaistallennettu julkaisuarkistoon.

Ammattikorkeakouluissa avointen julkaisujen kokonaisosuus kaikista raportoiduista vertaisarvioiduista julkaisuista oli selkeästi yliopistoja suurempi, yhteensä 47,9 \%. OA-julkaisukanavissa julkaiseminen oli ammattikorkeakouluissa noin kaksi kertaa niin yleistä kuin yliopistoissa keskimäärin, rinnakkaistallentaminen oli sen sijaan jonkin verran yliopistoja harvinaisempaa.

Taulukko 1: OA-julkaisujen osuus korkeakoulujen vuoden 2016 vertaisarvioiduista artikkeleista (julkaisutyypit A1-A4). Kategoriassa RT+ (rinnakkaistallennettu+) on mainittu niiden rinnakkaistallennettujen artikkelien määrä, jotka eivät ole avoimesti saatavilla muuta kautta. Taideyliopiston OA-julkaisujen määrää on korjattu.

\begin{tabular}{|c|c|c|c|c|c|c|c|}
\hline Yliopisto & Julkaisut yht & OA-kanava & Muu OA & RT & OA yht. & OA:n osuus & $\mathrm{RT}+$ \\
\hline Aalto-yo & 3141 & 417 & 136 & 648 & 792 & $25,2 \%$ & 239 \\
\hline Hanken & 210 & 39 & 9 & 22 & 54 & $25,7 \%$ & 6 \\
\hline Helsingin yo & 6971 & 1096 & 142 & 1515 & 1747 & $25,1 \%$ & 509 \\
\hline Itä-Suomen yo & 2347 & 559 & 117 & 265 & 723 & $30,8 \%$ & 47 \\
\hline Jyväskylän yo & 1880 & 386 & 60 & 947 & 984 & $52,3 \%$ & 538 \\
\hline Lapin yo & 329 & 109 & 1 & 23 & 120 & $36,5 \%$ & 10 \\
\hline Lappeenrannan tekn. yo & 820 & 257 & 4 & 4 & 262 & $32,0 \%$ & 1 \\
\hline Oulun yo & 2251 & 406 & 105 & 334 & 619 & $27,5 \%$ & 108 \\
\hline Taideyo & 60 & 24 & 1 & o & 25 & $41,7 \%$ & o \\
\hline Tampereen tekn. yo & 1501 & 264 & 30 & 278 & 417 & $27,8 \%$ & 123 \\
\hline Tampereen yo & 1874 & 423 & 107 & 366 & 580 & $30,9 \%$ & 50 \\
\hline Turun yo & 2999 & 618 & 270 & 725 & 1143 & $38,1 \%$ & 255 \\
\hline Vaasan yo & 313 & 58 & 35 & 30 & 110 & $35,1 \%$ & 17 \\
\hline Åbo akademi & 870 & 178 & 27 & 33 & 212 & $24,4 \%$ & 7 \\
\hline Kaikki yo:t & 22848 & 4265 & 768 & 4227 & 6600 & $28,9 \%$ & 1567 \\
\hline Kaikki amk:it & 695 & 264 & 31 & 99 & 333 & $47,9 \%$ & 38 \\
\hline
\end{tabular}

Yliopistojen osalta on hyvä pitää mielessä, että ne ovat julkaisuvolyymiltaan hy- 


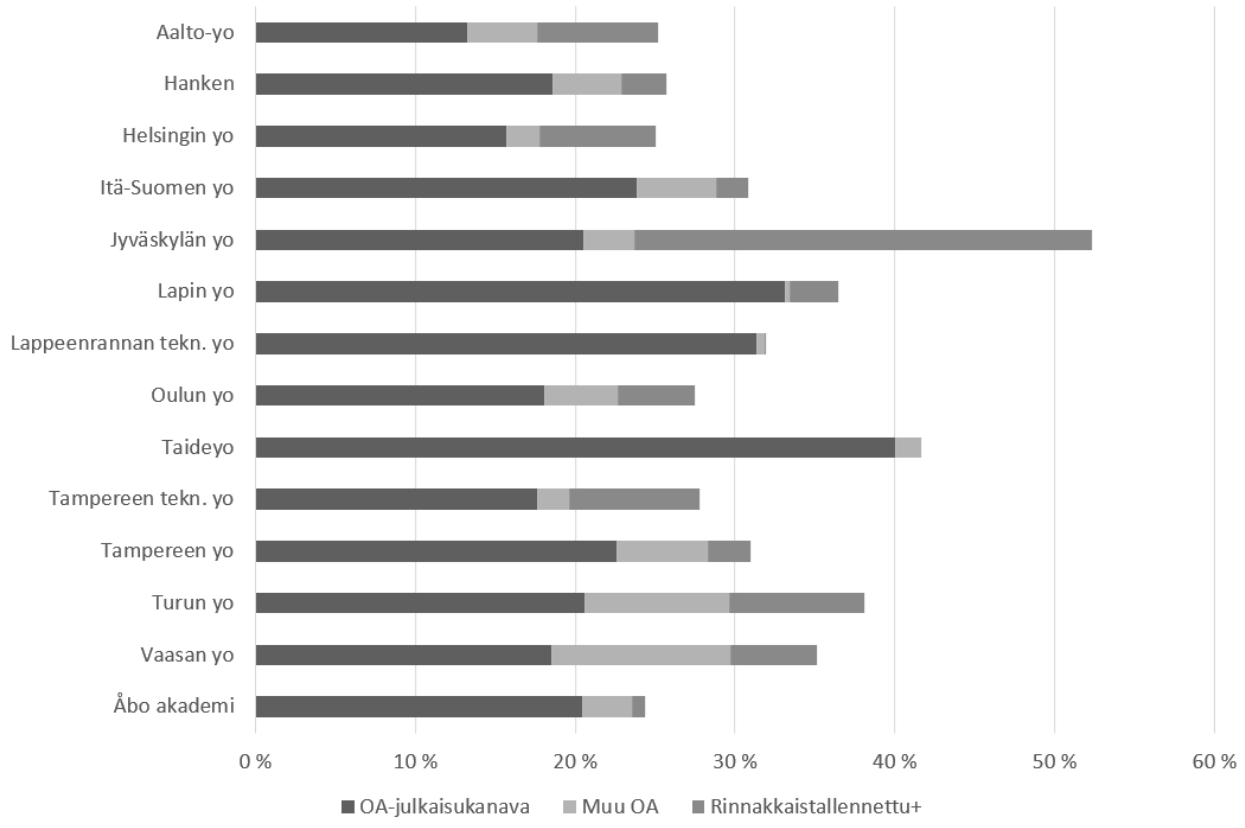

Kuva 2: OA-julkaisujen osuus yliopistojen vuoden 2016 vertaisarvioiduista artikkeleista (julkaisutyypit A1-A4). Taideyliopiston OA-julkaisujen osuutta on korjattu.

vin erikokoisia. Niinpä vaikka OA-julkaisujen osuus on Helsingin yliopistossa kansallista keskiarvoa alhaisempi, yliopistossa tuotettujen OA-julkaisujen absoluuttinen määrä (1747) on silti huomattavasti muita yliopistoja suurempi. Toisaalta pienempien yliopistojen osalta myös satunnaisilla tekijöillä saattaa olla näkyvää vaikutusta organisaation kokonaistilanteeseen. Esim. Lappeenrannan teknillisessä yliopistossa yli kolmasosa yliopiston kaikista vertaisarvioiduista OA-julkaisuista oli kahden fysiikan alan kansainvälisessä tutkimusyhteistyössä profiloituneen tutkijan (yhteistä) tuotantoa.

Alkuperäisessä Juulista poimitussa datassa Taideyliopisto oli raportoinut yli 60 $\%$ julkaisuistaan OA-julkaisukanavissa ilmestyneiksi. Koska OA-julkaisujen osuus näytti merkittävästi muita yliopistoja suuremmalta, tarkistin näiden julkaisujen tiedot yksitellen, jolloin noin kolmasosa tiedoista osoittautui virheellisiksi. Taulukossa 1 ja kuvassa 2 on käytetty Taideyliopiston osalta näitä korjattuja tietoja. Vastaavia - vaikkei ehkä prosentuaalisesti yhtä suuria - virheitä saattaa esiintyä myös muiden yliopistojen raportoimassa datassa, mutta suurempien julkaisumäärien vuoksi kaikkien organisaatioiden tietojen tarkistaminen ei kuitenkaan ollut tässä yhteydessä mahdollista.

OA-julkaisujen kokonaisosuus julkaisuista vaihteli vuonna 2016 yliopistoittain 
24 \%:n ja 52 \%:n välillä. Yliopistojen välillä on myös selkeitä eroja sen suhteen, onko avoin saatavuus toteutunut kustantajan tarjoaman palvelun vai rinnakkaistallennuksen kautta. OA-julkaisukanavissa ilmestyneiden julkaisujen osuus vaihteli yliopistoittain noin $13 \%$ :sta $40 \%$ :iin. Lukuja tarkasteltaessa on kuitenkin syytä pitää mielessä, että kunkin yliopiston tiedonkeruussa käyttämät metodit vaikuttavat raportoinnin kattavuuteen ja tietojen laatuun.

Joissakin yliopistoissa (esim. Jyväskylä) julkaisujen OA-status tarkastetaan kirjastossa julkaisukohtaisesti, kun taas esim. Helsingin yliopisto on ainakin toistaiseksi tehnyt tarkastuksen suurelta osin automaattisesti DOAJ:in lehtilistan ja yliopiston omaan Helda-julkaisuarkistoon rinnakkaistallennettujen julkaisujen pohjalta. Tutkijoiden itsenäisesti yliopiston Tuhat-tutkimustietojärjestelmään tallentamien julkaisujen OA-statusta koskevien tietojen hyödyntäminen on sen sijaan ollut hankalaa, koska tiedot on jäsennetty järjestelmässä eri tavalla kuin OKM:n tiedonkeruussa (Karhula, 2017). Niinpä on perusteltua olettaa, että OA-julkaisujen osuus Helsingin yliopiston kaikista julkaisuista on todellisuudessa ollut yliopiston raportoimia lukuja suurempi. Koska Helsingin yliopiston julkaisuvolyymi vastaa miltei kolmasosaa yliopistojen kaikista julkaisuista, sen luvuilla on suuri vaikutus kansallisiin keskiarvoihin.

Yliopistokohtaisten erojen taustalla on toki muitakin tekijöitä kuin mahdolliset eroavaisuudet tiedonkeruun käytännöissä. Yliopiston tieteenalavalikoima saattaa myös vaikuttaa OA-julkaisemisen yleisyyteen, sillä eri alojen julkaisukulttuureissa on selkeitä eroja. Lisäksi OA-julkaisemiseen yleisyyteen voivat vaikuttaa yliopistokohtaiset OA-politiikat ja tutkijoille tarjotut tukipalvelut.

OA-julkaisujen kokonaisosuutta tarkasteltaessa on syytä huomata, että niiden yhteenlaskettu määrä on merkittävästi pienempi kuin eri OA-kategorioihin sijoittuvien julkaisujen määrien yhteenlaskettu summa. Ilmiön selitys on se, että osa yliopistoista on ryhtynyt systemaattisesti keräämään julkaisuarkistoonsa OA-julkaisukanavissa ilmestyneitä artikkeleita, joiden oikeudet on määritelty CC-lisensseillä ja jotka siten voi rinnakkaistallentaa ilman erillistä lupaprosessia. Noin 60 \% rinnakkaistallennetuista artikkeleista onkin ollut jo alun perin avoimesti saatavilla myös kustantajan palvelun kautta.

Julkaisujen avoin saatavuus on yleisintä Jyväskylän yliopistossa, jossa OA-julkaisujen osuus vuoden 2016 julkaisuista oli yli 52 \%. Erityisen selkeästi Jyväskylän yliopisto erottuu muista siinä, että rinnakkaistallennus on siellä hallitseva avoimuuden väylä. Ero tulee näkyviin varsinkin silloin kun tarkastellaan niiden rinnakkaistallennettujen artikkelien osuutta (taulukoissa ja kuvissa "Rinnakkaistallennettu+"), jotka eivät ole ilmestyneet OA-kanavissa. Jyväskylässä rinnakkaistallentamisen tuottama lisä avointen julkaisujen osuuteen oli 28,6 \% yliopiston koko julkaisutuotannosta, kun taas mikään muu yliopisto ei yltänyt edes kymmeneen prosenttiin. 


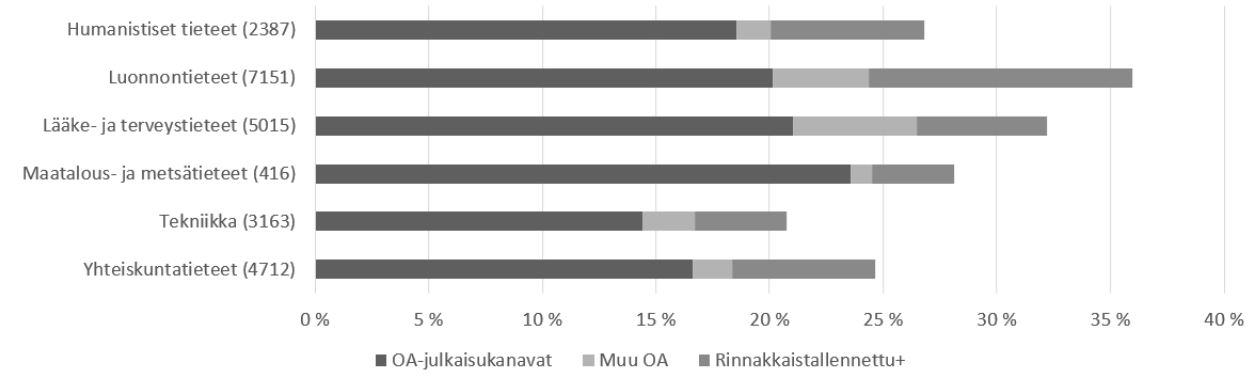

Kuva 3: OA:n osuus yliopistojen vuoden 2016 vertaisarvioiduista artikkeleista (julkaisutyypit A1-A4) päätieteenaloittain jaoteltuna. Artikkelien kokonaismäärät suluissa.

Jyväskylän yliopiston suuria lukuja voi tuskin pitää suurena yllätyksenä, sillä yliopiston kirjasto (vuoden 2017 alusta Avoimen tiedon keskus) on panostanut rinnakkaistallentamisen tukemiseen pitkäjänteisesti. Se on saanut lisätukea rinnakkaistallennukseen liittyvien käytäntöjen kehittämiseen myös OKM:n Avoin tiede ja tutkimus -hankkeen osana rahoitetun Suomi rinnakkaistallennuksen mallimaaksi -hankkeen kautta (Olsbo, 2017b).

\section{Julkaisujen avoimuus tieteenaloittain}

Keskeinen etu OA-tietojen keräämisestä OKM:n tiedonkeruun yhteydessä on se, että niitä on mahdollista yhdistää muihin tiedonkeruussa kerättyihin julkaisua koskeviin tietoihin. Julkaisutyyppi- tai organisaatiokohtaisen analyysin lisäksi OA-tiedot on mahdollista yhdistää esim. julkaisujen tieteenaloihin, tekijöiden määrään tai Julkaisufoorumi-luokituksiin.

Tieteenalojen osalta Juuli-julkaisuportaalin fasetit perustuvat julkaisuille raportoituihin ensimmäisiin tieteenaloihin. Julkaisujen tieteenalojen määrittelyä on eri organisaatioissa tehty erilaisilla perusteilla, joskus pikemminkin paikallisiin organisaatiorakenteisiin kuin julkaisujen sisältöön perustuen, mikä tuo tietoihin jonkin verran sattumanvaraisuutta. Päätieteenalojen tasolla tästä johtuvat ongelmat kuitenkin tasoittuvat.

Kuvassa 3 esitetyt vertaisarvioituja artikkeleita koskevat tulokset heijastelevat alakohtaisten julkaisukulttuurien eroja. Luonnontieteissä, lääke- ja terveystieteissä sekä maatalous- ja metsätieteissä julkaisutoiminta keskittyy lehtiartikkeleihin, joissa avointen julkaisujen osuus on suurin. Humanistis-yhteiskuntatieteellisillä aloilla puolestaan julkaistaan lehtiartikkelien lisäksi paljon myös kokoomateosartikkeleita, joista on vapaasti saatavilla vain noin $13 \%$. Tekniikan alalla suuri osa artikkeleis- 


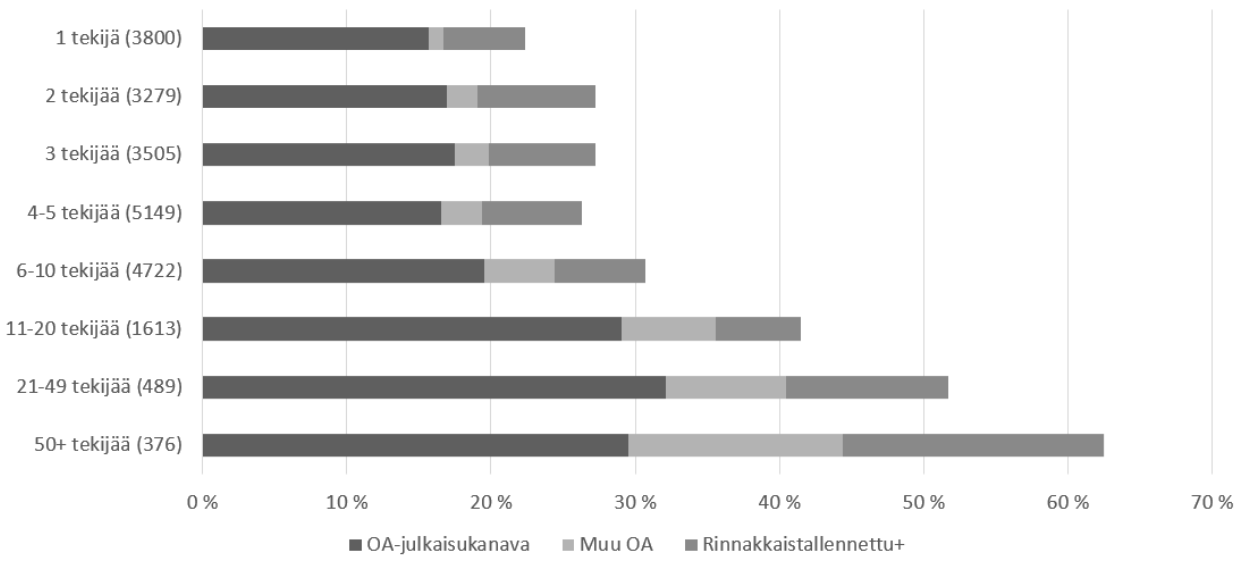

Kuva 4: OA-julkaisujen osuus suhteessa tekijämäärään yliopistojen yliopistojen vuoden 2016 vertaisarvioiduissa artikkeleissa (julkaisutyypit A1-A4). Kuvassa on käytetty tekijämäärien osalta Juuli-portaalin ryhmittelyä, vaikkei se ole säännönmukainen. Artikkelien kokonaismäärät suluissa.

ta ilmestyy konferenssijulkaisuissa, joissa avointen julkaisujen osuus on niin ikään pienempi kuin tieteellisissä lehdissä.

Jos tarkastellaan pelkästään vertaisarvioituja lehtiartikkeleita (julkaisutyypit A1A2) tulokset näyttävät jossain määrin tasaisemmilta. Luonnontieteissä avointen julkaisujen osuus on tällöinkin selkeästi suurin ( $38 \%)$, mutta humanistiset tieteet (33 $\%$ ) nousevat aavistuksen verran lääke- ja terveystieteiden (32\%) edelle ja yhteiskuntatieteetkin ( $28 \%$ ) yltävät maatalous- ja metsätieteiden (30\%) tuntumaan. Tekniikan alalla (23\%) avoin saatavuus näyttää sen sijaan olevan myös lehtiartikkeleiden osalta selkeästi harvinaisempaa kuin muilla tieteenaloilla. Tekniikan alan julkaisujen osalta saattaisi tosin olla perusteltua tarkastella sitä, onko teknillisten yliopistojen tiedonkeruukäytännöissä sellaisia tekijöitä, jotka selittävät näin suurta eroa muihin tieteenaloihin.

\section{Tekijöiden määrän suhde julkaisujen avoimuuteen}

Juulin käyttöliittymässä käytetty julkaisujen tekijämäärien ryhmittely on jossain määrin mielivaltainen, mutta sen perusteella (kuva 4) saa kuitenkin yleiskäsityksen siitä, miten tekijöiden määrä korreloi julkaisun avoimen saatavuuden kanssa. Suurimpien tekijämäärien osalta on syytä huomata, että OKM:n julkaisutiedonkeruun ohjeistuksen mukaan yli 50 tekijän artikkelien tarkkaa tekijämäärää ei tarvitse laskea, vaan määräksi voi tällöin ilmoittaa 50.

Yhden tekijän artikkelit ovat harvemmin avoimesti saatavilla kuin usean tekijän 
yhteiset artikkelit. Yli kymmenen tekijän artikkelien osalta OA-julkaisujen osuus on selkeästi suurempi kuin alle kymmenen tekijän artikkeleilla, ja viidenkymmenen tai useamman tekijän artikkelien kohdalla avointen julkaisujen osuus on yli 60 $\%$. Ilmiö selittynee osin sillä, että suuret tekijämäärät ovat tyypillisiä esim. fysiikan alalle, jolla julkaisujen avoimuus on muutenkin yleistä.

Suurten tekijämäärien artikkelit ovat yleensä kansainvälisiä yhteisjulkaisuja, eli voi olettaa, että monet niistä on rinnakkaistallennettu Suomen lisäksi muissakin maissa. Tämä ei välttämättä näy kaikkien organisaatioiden raportoimassa datassa, koska osa niistä ilmoittaa tällä hetkellä rinnakkaistallennetuiksi vain ne julkaisut, jotka on tallennettu organisaation omaan julkaisuarkistoon. Avointen julkaisujen osuus voi siis tältä osin olla raportoitua suurempi. Tekijämäärien kasvaessa myös hybridi-OA:n osuus kasvaa.

\section{Avoimet julkaisut ja Julkaisufoorumi}

Julkaisukanavien laatuun perustuviin mittareihin kytketty meritoituminen ja vaatimukset julkaisujen avoimuudesta saattavat johtaa tutkijan kannalta ristiriitaisiin tilanteisiin. Pitäisikö julkaisukanavan valinnassa priorisoida mieluummin mahdollisimman arvostettua julkaisukanavaa vai julkaisukanavan avoimuutta? Arvostetuimmat julkaisukanavat ovat tällä hetkellä suhteellisen harvoin avoimia, minkä on yleisesti nähty hidastavan siirtymistä kohti avointa julkaisemista.

Suomessa tämä keskustelu on kytkeytynyt usein Julkaisufoorumiin (ks. esim. Happonen, 2017; Olsbo, 2013), jonka tekemää julkaisukanavien tasoluokitusta on hyödynnetty vuodesta 2015 lähtien myös yliopistojen rahoitusmallissa. Julkaisufoorumin tasoluokituksessa taso yksi on perustaso, taso kaksi johtava taso ja tasolle kolme sijoittuvat kaikkein korkeatasoisimmat julkaisukanavat. Luokat eivät ole kooltaan yhtä suuria, sillä ylemmille tasoille kelpuutettavien julkaisukanavien osuus on rajattu alakohtaisesti julkaisuvolyymin perusteella $20 \%$ :iin ko. alan kaikista tieteellisistä julkaisuista. Tason kolme julkaisukanavien osuus voi puolestaan olla korkeintaan viisi prosenttia julkaisuvolyymista (TSV, 2017).

Suurin osa Julkaisufoorumin luokittelemista OA-julkaisukanavista sijoittuu tällä hetkellä tasolle yksi, kun taas ylemmillä tasoilla välittömän avoimuuden periaatteella toimivia lehtiä on suhteellisen vähän (Happonen, 2017; Ruth, 2017). Lisäksi on huomionarvoista, että julkaisuvolyymiltaan merkittävät ns. megalehdet ( $\mathrm{mm}$. PloS One ja Scientific Reports) sijoittuvat luokituksessa tasolle yksi. Näissä ilmestyy vuosittain satoja suomalaisten tutkijoiden julkaisuja.

Kuvassa 5 on tarkasteltu yliopistolaisten julkaisemien vertaisarvioitujen lehtiartikkelien (julkaisutyypit A1-A2) julkaisukanavien Julkaisufoorumi-luokituksia. Osuuksissa ei ole mukana kokoomateoksissa tai konferenssijulkaisuissa ilmestyneitä artik- 


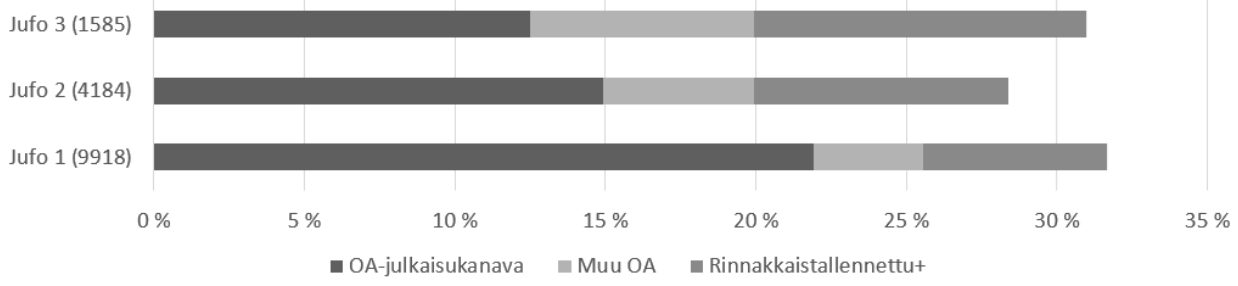

Kuva 5: OA:n osuus suhteessa lehtien Julkaisufoorumi-luokituksiin yliopistojen vuoden 2016 vertaisarvioiduissa artikkeleissa (julkaisutyypit A1-A2). Artikkelien kokonaismäärät suluissa

keleita. Näiden osalta avointen julkaisujen osuus on pienempi ja julkaisukanavan taso määrittyy usein kustantajan, ei julkaisusarjan perusteella.

Yleisenä havaintona voi todeta, että avoin saatavuus on tasolle kaksi luokiteltujen lehtien osalta jonkin verran harvinaisempaa kuin tasoilla yksi tai kolme. Tasojen välillä on kuitenkin huomattavasti suurempia eroja sen suhteen, millä tavalla julkaisujen avoimuus on toteutunut.

Kuten Julkaisufoorumin OA-julkaisukanaville antamien luokitusten perusteella voi odottaakin, OA-kanavien osuus on suurin tasolla yksi, mutta pienenee merkittävästi tasoilla kaksi ja kolme. Vaikka OA-julkaisukanavien osuus on arvostetuimpien julkaisukanavien kohdalla pienempi, rinnakkaistallentaminen ja hybridi-OA kuitenkin kompensoivat tilannetta. Rinnakkaistallenteiden osuus kasvaa ylemmillä tasoilla, ja tämän reitin merkitys näyttää olevan selkeästi suurin tasolla kolme. Samoin hybridijulkaisukanavissa ilmestyvien OA-artikkelien osuus on tasoilla kaksi ja kolme suurempi kuin tasolla yksi.

\section{Kehittämismahdollisuuksia}

Kuten edellä on osoitettu, OKM:n tiedonkeruussa kerättyjen tietojen pohjalta on mahdollista analysoida suomalaisten yliopistojen tuottamien julkaisujen avointa saatavuutta useista eri näkökulmista. Analyyseissä käytetty data on koottu käsin Juuli-julkaisutietoportaalista, jossa ei hyödynnetä kaikkia tiedonkeruun kenttiä. Virta-tietovarannon sisältämän ja sieltä rajapintojen kautta saatavilla olevan raakadatan pohjalta olisi mahdollista tehdä vielä monipuolisempia analyysejä myös automaattisesti. Toisaalta tietuetason tietojen häivyttäminen näkyviltä ja tietojen käsittely pelkkinä numeroina voi johtaa joissakin tapauksissa harhaan, sillä datan laadussa on toistaiseksi monenlaisia puutteita, jotka eivät tällöin nouse esiin.

Tällä hetkellä Virran ja Juulin sisältämiä yliopistojen OA-tietoja on mielekästä 
analysoida vain vuoden 2016 osalta. Tietojen laatuun liittyvistä varauksista huolimatta yliopistoilta kerättyjä lukuja voi tältä osin pitää ensimmäistä kertaa vähintään suuntaa-antavina. Tulevina vuosina niiden pohjalta on mahdollista muodostaa aikasarjoja, joiden avulla on mahdollista seurata avointen julkaisujen osuudessa tapahtuvia muutoksia.

Julkaisutietojen keruuseen ja tarkistamisen liittyvien prosessien kehittäminen edellyttää yhteistyötä ja merkittävää panostusta myös jatkossa. Tähän liittyen on perusteltua käydä keskustelua siitä, missä määrin ja millä tavalla yksittäisten tietojen keruussa ja tarkistamisessa voidaan hyödyntää kehittymässä olevia kansallisia ja globaaleja infrastruktuureja. Tämä edellyttää selvityksiä muista järjestelmistä saatavien tietojen laadusta, mahdollisten teknisten integraatioiden toteutustavoista ja eri järjestelmien välisten tietovirtojen muodostamasta kokonaisuudesta.

Järjestelmien välisiin yhteyksiin liittyvää suunnittelua tehdään jo mm. OKM:n CSC:ltä tilaaman kansallisen tutkimustietovarannon suunnittelun yhteydessä (CSC, 2017). Kansainvälisellä tasolla julkaisuja koskevien tietojen laatua ja yhteismitallisuutta kehitetään useassa yhteydessä, tuoreimpana esimerkkinä CrossRefin yhdessä useiden muiden toimijoiden kanssa käynnistämä Metadata 2020 -yhteenliittymä (Metadata 2020, 2017). Pitkällä tähtäimellä olisi eduksi, jos julkaisujen tiedot luotaisiin mahdollisimman pitkälle jo kustantajien järjestelmissä, josta ne sitten siirtyisivät aineistojen kuvailutietojen mukana muihin järjestelmiin. Julkaisuun liittyvät tiedot täydentyisivät vähitellen eri järjestelmissä, joiden tietosisällöt olisi mahdollista linkittää toisiinsa mm. pysyvien tunnisteiden avulla.

OA-tietojen osalta mahdollisia kansainvälisiä tietolähteitä ovat mm. oaDOIpalvelu, DOAJ ja Sherpa-Romeo-tietokanta. Niistä poimittua dataa on osin jo nyt mahdollista hyödyntää sekä organisaatiotasolla paikallisissa tutkimustietojärjestelmissä että kansallisen tason keskitetyissä järjestelmissä, ml. Julkaisufoorumin julkaisukanavatietokanta (Ruth, 2015). Julkaisutoiminnan ja sitä tukevien järjestelmien muutokset saattavat avata mahdollisuuksia yhdistää OKM:n tiedonkeruussa koottuun dataan myös uudentyyppisiä tietoja. Näistä voi mainita mm. OA-julkaisuista maksettavia artikkelimaksuja koskevat tiedot ja julkaisujen vaikuttavuudesta kertovat data-aineistot.

Artikkelimaksuja koskevia tietoja on viime aikoina kerätty ja julkaistu avoimena datana useissa Euroopan maissa (Intact Project, 2017), ei tosin vielä Suomessa. Tiedoista olisi hyötyä mm. FinELib-konsortion kansainvälisten kustantajien kanssa käymissä neuvotteluissa, joissa lisenssisopimuksiin pyritään kytkemään open access -elementtejä (Tuuliniemi, 2017). OKM:n tiedonkeruussa käytetyt julkaisun OA-statusta määrittelevät kategoriat eivät ota kantaa siihen, onko julkaisusta maksettu artikkelimaksua vai ei. Näin voisi olla myös jatkossa, jos tiedonkeruuseen lisättäisiin kenttä, jossa artikkelimaksun maksanut organisaatio voi raportoida sen suuruuden. Tietojen saaminen mukaan tiedonkeruuseen edellyttäisi tosin sitä, että 
organisaatiot hallinnoisivat artikkelimaksuja keskitetysti ja yhdistäisivät niitä koskevat tiedot tutkimustietojärjestelmään tallennettuihin julkaisutietoihin.

Julkaisujen erilaisissa verkkopalveluissa saamaa huomiota mittaavan altmetriikka-datan yhdistämistä OKM:n julkaisudataan on jo kokeiltu Turun yliopiston ATThankkeen rahoituksella toteuttamassa projektissa (Kutilainen, 2017). Julkaisuihin kohdistuneiden viittausten tiedot ovat aiemmin olleet saatavilla kootusti lähinnä Web of Sciencen ja Scopuksen kaltaisissa maksullisissa tietokannoissa, mikä on tehnyt niiden jatkokäytön muissa järjestelmissä hankalaksi. Keväällä 2017 julkistettu Initiative for Open Citations -yhteenliittymä on kuitenkin pystynyt nopeassa tahdissa avaamaan vapaaseen käyttöön lähes puolet kaikista viittaustiedoista (Open Citations, 2017). Nämä aineistot tarjoavat uusia mahdollisuuksia arvioida avointen julkaisujen vaikuttavuutta ja avoimuuden mahdollisesti tuottamaa etua muihin julkaisuihin verrattuna.

\section{Suomalaiset julkaisut ja avoimuus}

OKM:n keräämien julkaisutietojen perusteella avointen julkaisujen osuus suomalaisten yliopistojen vertaisarvioiduista julkaisuista oli $28,9 \%$ vuonna 2016 . Tiedonkeruussa tapahtuneista muutoksista johtuen vuoden 2016 tietoja ei ole mielekästä verrata aiempina vuosina kerättyihin tietoihin, mutta on kuitenkin todennäköistä, että avointen julkaisujen osuus on kasvanut, sekä kustantajien palveluissa avoimesti saatavilla olevien julkaisujen että rinnakkaistallenteiden osalta. Vaikka OAjulkaisujen todellinen osuus saattaa edelleen olla jonkin verran tiedonkeruun tietojen pohjalta laskettua lukua suurempi, on kuitenkin jo ilmeistä, ettei ATT-hankkeen vuodelle 2017 tavoitteeksi asettaman 65 \%:in OA-osuuden tavoittaminen ole käytännössä mahdollista.

Vaikka OA-julkaisujen osuus on Suomessa toistaiseksi virallisia tavoitteita alhaisempi, vaikuttaa kuitenkin siltä, ettei Suomen tilanteessa ole tältä osin mitään erityisen poikkeuksellista. Tilastointimetodien ja tilastoinnissa käytettyjen kategorioiden eroista johtuen OA-julkaisujen osuutta koskevien kansainvälisten vertailujen tekeminen on toistaiseksi hankalaa. Ainakin Iso-Britannia, jossa avoimen julkaisemisen tukemiseen on satsattu paljon, lienee selkeästi Suomea edellä (Universities UK Open Access Coordination Group, 2017).

Muut pohjoismaat tarjoavat luontevimman vertailukohdan Suomelle. Norjalaisten julkaisutietojen pohjalta tehdyt analyysit (Mikki, 2017) poikkeavat käytettyjen menetelmien ja avoimuuden määritelmien osalta tässä artikkelissa esitetyistä, mutta Ruotsin ja Tanskan osalta saatavilla on tietoja, jotka ovat melko hyvin yhteismitallisia Suomen kanssa. Ruotsissa SwePub-tietokannan ja OaDOI:n datan 
pohjalta tehdyn analyysin perusteella avointen julkaisujen osuus kaikista vertaisarvioiduista artikkeleista oli vuonna 2016 yhteensä $39 \%$. Kultaisen (18 \%) ja hybridiOA:n ( $5 \%$ ) osuus oli Ruotsissa suurin piirtein sama kuin Suomessa, mutta rinnakkaistallentamisen (33\%) merkitys oli selkeästi suurempi (Kronman, 2017).

Tanskassa julkaisujen avoimuuden nopealle yleistymiselle on asetettu samanlaisia kunnianhimoisia tavoitteita kuin Suomessa. Tanskalaisten linjausten mukaan OA-julkaisujen osuus olisi pitänyt olla 80 \% vuonna 2016 ja $100 \%$ vuonna 2021. Tanskan vuoden 2016 lukuja ei ole vielä julkaistu, mutta vuosina 2013-2015 avointen julkaisujen osuus oli noussut $17 \%$ :sta $23 \%$ :iin (Forskningsdatabasen, 2017), eli hyppäys yhdessä vuodessa 80 \%:iin vaikuttaa sielläkin epätodennäköiseltä.

ATT-hankkeen asettamien pidemmän aikavälin tavoitteiden saavuttaminen edellyttää joka tapauksessa edelleen sekä poliittisia päätöksiä että runsaasti pitkäjänteistä työtä. Eri alojen julkaisukulttuureissa on merkittäviä eroja, joiden vuoksi avoimuuden edistämiseksi voi olla mielekästä kehittää erilaisia toimintamalleja. Kuten tähänkin asti, julkaisujen avoimuus voi toteutua monia eri reittejä.

\section{Kirjoittajan sidonnaisuudet}

Kirjoittaja on toiminut Juuli-julkaisutietoportaalin vastuuhenkilönä Kansalliskirjastossa ja osallistunut OKM:n julkaisutiedonkeruussa käytetyn open access -määritelmän suunnitteluun.

\section{Artikkeliin liittyvä data}

Tätä artikkelia varten Juulista poimitut tilastotiedot ja niiden pohjalta tehdyt laskelmat ovat saatavilla Kansalliskirjaston julkaisuarkistossa (Ilva, 2017a).

\section{Lähteet}

ATT-hanke. (ei pvm.). Avoin tiede ja -tutkimus - Tavoitteet. https://avointiede.fi/att-tavoitteet (luettu 23.12.2017)

Budapest Open Access Initiative. (2002). Budapest Open Access Initiative. http://bit.ly/budapestoa (luettu 23.12.2017)

Chawla, D. S. (2017). Unpaywall finds free versions of paywalled papers. Nature. https://oadoi.org/ 10.1038 /nature.2017.21765

CSC. (2017). Tutkimustietovaranto. https://wiki.eduuni.fi/display/CSCTTV/ (luettu 16.12.2017)

Forskningsdatabasen. (2017). Open Access Indicator - Statistics for 2015. http: //www. forskningsdatabasen . $\mathrm{dk}$ /en/open_access/overview (luettu 16.12.2017)

Happonen, K. (2017). University funding model discriminates against Open Access publishing. Vii- 
te - Tieteen ja teknologian vihreät. http://www.viite.fi/2017/09/22/university-funding-modeldiscriminates-against-open-access-publishing/ (luettu 16.12.2017)

Ilva, J. (2013). Yliopistojen julkaisutiedot Juuliin. CSC Tieteen tietotekniikka 2/2013. http://urn.fi/ URN : NBN: fi-fe201310236855 (luettu 16.12.2017)

Ilva, J. (2015a). Kohti yhteismitallisuutta: avoimen julkaisemisen mittarit. Tietolinja 2/2015. http:// urn.fi/URN: NBN: fi-fe2015092113661 (luettu 16.12.2017)

Ilva, J. (2015b). OKM:n tiedonkeruun avoin saatavuus -tieto. Selvitys, 2.3.2015. http://urn. fi/URN: NBN : fi-fe2015090111081 (luettu 16.12.2017)

Ilva, J. (2017a). Suomalaisten yliopistojen vuoden 2016 julkaisujen avoimuutta koskevia tilastotietoja. http://urn.fi/URN:NBN: fi-fe2017101450098 (luettu 16.12.2017)

Ilva, J. (2017b). Towards Reliable Data - Counting the Finnish Open Access Publications. Procedia Computer Science, 106, 299-304. https://oadoi.org/10.1016/j.procs.2017.03.029

Intact Project. (2017). Open APC - INTACT Project. https: //www. intact-project .org/openapc/ (luettu 16.12.2017)

JURE-projekti. (2010). Jure-projektin sisältötyöryhmän raportti. http://urn.fi/URN: NBN: fi-fe2017111450691 (luettu 16.12.2017)

Karhula, P. (2017). Pekka Karhulan sähköpostiviesti 4.7.2017.

Kronman, U. (2017). Open Access i SwePub 2010 - 2016 (No. 6.6-2017-354). National Library of Sweden. http://bit.1y/oa-i-swepub-2010-2016 (luettu 30.12.2017)

Kutilainen, T. (2017). FImpact: eniten verkkohuomiota saaneet suomalaistutkimukset - Portti. ATT Avoin tiede ja tutkimus. https://portti.avointiede.fi/tutkimusmenetelmat/fimpact-eniten-verkkohuomiotasaaneet-suomalaistutkimukset (luettu 16.12.2017)

Laakso, M., \& Björk, B.-C. (2013). Delayed open access: An overlooked high-impact category of openly available scientific literature. Journal of the American Society for Information Science and Technology, 64(7), 1323-1329. https://oadoi.org/10.1002/asi.22856

Laakso, M., \& Björk, B.-C. (2016). Hybrid open access-A longitudinal study. Journal of Informetrics, 10(4), 919-932. https://oadoi.org/10.1016/j.joi.2016.08.002

Matthews, D. (2016). Do academic social networks share academics' interests? Times Higher Education. https://www.timeshighereducation.com/features/do-academic-social-networks-share-academicsinterests (luettu 16.12.2017)

Metadata 2020. (2017). Metadata 2020. http://www. metadata2020.org/ (luettu 16.12.2017)

Mikki, S. (2017). Scholarly publications beyond pay-walls: increased citation advantage for open publishing. Scientometrics, 113(3), 1529-1538. https://oadoi.org/10.1007/s11192-017-2554-0

OKM. (2016). OKM:n yliopistojen tiedonkeruukäsikirja 2016. https://oadoi.org/10.5281/zenodo. 1134089

Olsbo, P. (2013). Julkaisufoorumi ja Open Access. Tieteen julkisuus -seminaarissa (12.4.2013) pidetty esitelmä. http://urn.fi/URN:NBN: fi:jyu- 201304171451 (luettu 16.12.2017)

Olsbo, P. (2017a). Measurement of Open Access as an Infrastructural Challenge : The Case of Finland. Teoksessa Expanding Perspectives on Open Science : Communities, Cultures and Diversity in Concepts and Practices. Proceedings of the 21st International Conference on Electronic Publishing (ss. 217-226). IOS Press. https://oadoi.org/10.3233/978-1-61499-769-6-217

Olsbo, P. (2017b). Rinnakkaistallentaminen etenee Suomessa: Suomi rinnakkaistallentamisen mallimaaksi-hankkeen loppuraportti. Jyväskylän yliopisto. http://urn.fi/URN: NBN: fi : jyu- 201705052206 (luettu 16.12.2017)

Open Citations, I. for. (2017). I4OC - Initiative for Open Citations. https : //i4oc .org/ (luettu 23.12.2017)

Piwowar, H., Priem, J., Lariviere, V., Alperin, J. P., Matthias, L., Norlander, B., ... Haustien, S. (2017). The State of OA: A large-scale analysis of the prevalence and impact of Open Access articles. PeerJ Preprints. https://oadoi.org/10.7287/peerj.preprints.3119v1

Pölönen, J. (2017). The role of Finnish scholarly journals in the funding of universities. Presentation 
at the seminar "Scholarly journals, politics, and freedom of speech". Helsinki. http://urn.fi/URN: NBN: fi- fe201707037622 (luettu 16.12.2017)

Ruth, A.-S. (2015). Julkaisufoorumin tietokantasisällöt laajempaan käyttöön. Tietolinja 2/2015. http: //urn.fi/URN:NBN: fi- fe2015092113660 (luettu 30.12.2017)

Ruth, A.-S. (2017). Open access publishing and the question of quality. http://bit .ly/ruth-oa-qualitypresentation (luettu 23.12.2017)

TSV. (2017). Luokitteluperusteet julkaisufoorumi.fi. http://www.julkaisufoorumi.fi/fi/arvioinnit/ luokitteluperusteet (luettu 16.12.2017)

Tuuliniemi, A. (2017). FinELibin sopimusneuvottelut ja open access. Esitys Kirjastoverkkopäivien rinnakkaissessiossa "Tieteelliset lehdet ja open access", 26.10.2017. http://urn.fi/URN:NBN:fife2017103150419 (luettu 16.12.2017)

Universities UK Open Access Coordination Group. (2017). Monitoring the transition to open access: December 2017 (s. 51). http://www. universitiesuk.ac.uk/policy-and-analysis/reports/Pages/ monitoring-transition-open-access-2017. aspx (luettu 16.12.2017)

VIRTA-julkaisutietopalvelu. (ei pvm.). VIRTA-julkaisutietopalvelu - VIRTA-Julkaisutiedonkeruu. https : //wiki.eduuni.fi/display/cscvirtajtp/VIRTA-julkaisutietopalvelu (luettu 16.12.2017) 